\title{
The contribution of ineffective urban planning practices to disaster and disaster risks accumulation in urban areas: the case of former Kunduchi quarry site in Dar es Salaam, Tanzania
}

\section{Benedict F. Malele \\ Senior Planning Officer and Freelance Researcher, Ardhi University, \\ Dar es Salaam, Tanzania. \\ benedictmalele@yahoo.com/malele@aru.ac.tz}

\section{ABSTRACT}

This study examined the link between urban planning practices and disaster risks. The study used the former Kunduchi Quarry Site within the City of Dar es Salaam to demonstrate how laxity in enforcing the laid down planning rules, regulations and procedures facilitates the accumulation and occurrence of disaster risks and disasters in urban areas. This undermines one of the central roles of urban planning, which is to protect the lives of people from disaster risks and disasters. In exploring this, the study specifically focused on understanding the rules, regulations and procedures of planning in Tanzania; the extent to which they are followed and, where they are not followed, their implications for disaster risks and disasters; the coping initiatives adopted by local communities to reduce risks and their level of success or failure; and finally the drawing of lessons and recommendations for disaster risk reduction in urban areas. Strongly emerging from this study is the finding that although planning rules and regulations do exist, they are not enforced. As a result urban communities suffer from disaster risks and disasters caused by unregulated activities. The study analyzed the coping initiatives that urban communities apply to reduce disaster risks in their areas. It noted that, while a range of "coping" responses could be observed, these are not lasting solutions to the disaster risks being faced. Sustainable solutions seem to be known by the local community but they are not adopted for fear of compromising or undermining their existing livelihood strategies. 


\section{KEYWORDS}

urban planning practices, disaster and disaster risk reduction

\section{Introduction}

Like many other third word countries, Tanzania is being confronted by what many authors describe as human-induced disasters and disaster risks. Poor infrastructure and services and uncoordinated urban development, particularly in urban housing areas, which are reinforced by among other factors poor urban governance, often make urban dwellers, their properties and the environment in general more vulnerable to the impacts of a number of hazards like flooding, diseases, fires and pollution. Urban planning though is perceived as one of the tools for urban risk reduction, although this conception seems to apply differently within the urban areas of the developing world as demonstrated by the Kunduchi quarry site in Dar es Salaam city, Tanzania.

\section{The concept of disaster and disaster risk reduction}

In this study, Disaster Risk Reduction (DRR) is considered to mean the systematic development and application of policies, rules and regulations, procedures, strategies and practices to minimize vulnerabilities and disaster risks throughout the society to avoid (prevention), to limit (mitigation), or take precautions (preparedness) against the adverse impacts of hazards within the broad context of sustainable development (AU-NEPAD et al., 2004).

Disaster risk reduction initiatives continue to be very important and appropriate measures in avoiding or reducing the negative impacts of hazards. One of the approaches of DRR particularly in urban areas is "effective urban planning and management". Before dwelling on the discussion of how effectively urban planning and management (which essentially encompasses, among others, adherence to the laid down rules, regulations and procedures when developing in urban areas) contribute to disaster risk reduction, it is important to become acquainted with the basic principles and concepts of disaster and disaster risk reduction.

Understanding of the term disaster requires the understanding of hazard, risk, vulnerability, threat and small disaster. AU-NEPAD et al., (2004) conceive a hazard as a potentially damaging physical event, phenomenon or human activity, which may cause the loss of life or injury, property-damage, social and economic disruption or environmental degradation. Flooding, fire outbreak, cholera strike, tuberculosis (TB) outbreak, landslide, hurricane, thunderstorm, earthquakes to mention but a few, are good examples of potential physical phenomena/events or 
human activity, which may cause loss of life, property-damage, social and economic disruption or environmental degradation to the extent of disaster. The potentiality of these physical phenomena/events or man-made activities to cause negative impacts is what makes them qualify as being regarded as hazards. In other words, a hazard refers to any natural or human-made phenomenon/event that when exposed to vulnerable elements may cause loss of life or damage to property and environment.

AU-NEPAD et al., (2004) view vulnerability as a set of conditions and processes resulting from physical, social, economic and environmental factors, which increase the susceptibility of a community, property or environment to the impact of hazards. Poor urban communities with poorly constructed houses living in a flood prone area are more vulnerable to floods. For instance, Msimbazi valley in Dar es Salaam City in Tanzania is a flood prone area. However, about 6,187 households accommodating about 26,000 people stay within this flood prone area (Ngware, 2003). The majority of houses constructed within Msimbazi valley are also poor in their resistance to floods. This means that the area is in itself vulnerable to floods and the households staying within the valley are also vulnerable to the impacts of flooding, which may include loss of lives and properties. Likewise, a settlement/neighbourhood which lacks essential services such as police security, will in the event of crime, find that its residents are even more vulnerable to the impact of crime, which includes the loss of lives and properties. Basically, the level of vulnerability of a human being, property or environment is what influences the impact of hazard. The more vulnerable a human being, property or an environment is, the more severe the impacts it will have in the event of a hazard occurrence.

Risk is the probability of being associated with hazards and disasters, while a threat refers to imminent harm or danger or an event which is likely to inflict harm, or cause damage or disaster (Meshack et al., 2006). Therefore, a threat bears similarity to risk. Poor management of solid waste and sanitation in particular settlements or neighbourhoods is a threat to the health condition of the residents of that particular settlement. Likewise, a settlement/neighbourhood with poor management of its solid waste and sanitation system is at high risk of a disease outbreak. People who build within the flood prone areas like valleys have a high risk of floods and their impacts. Housing units, which lack proper road accessibility, are at high risk of not being assisted by fire engines and fire fighters if fires occur. 
A disaster refers to a remarkable occurrence (phenomenon) in which a significant number of people, properties and environments suffer severe damage, disrupting the livelihood system and thus making the affected society/population unable to cope by using its own resources. AU-NEPAD et al. (2004) define a disaster as a serious disruption of the functioning of a community or society causing widespread human, material, economic or environmental losses, which exceed the ability of the affected community/society to cope, using its own resources. A disaster happens when a hazard strikes on vulnerable elements like human beings, properties or the environment causing widespread human, material, economic or environmental losses, which exceed the ability of the affected to cope using their own resources. Good examples of disasters are the Tsunami event, which occurred in December 2004, affecting/devastating the lives of millions of people in Indonesia, India, Sri-Lanka and Thailand; the Katrina and Rita hurricanes, which occurred in August and September 2005 respectively, affecting the lives of hundreds of thousands of people mostly along the southern coast of the USA, the Stan hurricane that hit Central America (Guatemala and El-Salvador) and the south of Mexico killing more than 250 people, and the earthquakes that occurred in Pakistan, India and Afghanistan killing more than 30,000 people. A clear differentiation should be made between a hazard and a disaster as many people tend to mix up these terms. If an area experiences drought (which by itself is a hazard) for some time but the people of that particular area do not die of hunger as they have enough foodstuffs in stock, then this phenomenon cannot constitute a disaster. However, the same drought may lead to loss of animals due to lack of pastures and drinking water. When this happens this can amount to a disaster.

The empirical evidence discussed above, justifies the need for adopting disaster risk reduction approaches or tools so as to avoid or reduce the impact of hazards. The ProVention consortium notes that risk reduction involves measures to avoid (prevention), limit (mitigation) or take precautions against (preparedness) the destructive and disruptive effects of hazards, thus lessening potential impacts. The focus of risk reduction is vulnerability reduction, which includes a wide range of social, economic, environmental and technical issues. Risk reduction includes a range of structural measures such as flood defences or safe building design, as well as non-structural measures such as development of early warning systems or sensitization of the population at risk ${ }^{\mathrm{i}}$.

\section{Urban planning and management as a tool for disaster risk reduction}

As pointed out earlier, effective urban planning and management is one of the essential tools of disaster risk reduction in urban areas. Before dwelling in detail 
on this it is very important to recall that the urban planning profession had its roots in the 19th century during the climax of the industrial revolution. This revolution was accompanied by an uncontrollable influx of rural poor flooding into towns in search of employment opportunities. This growth both in population and activities became a challenge; as a result it led among other things to an insanitary living environment and diseases. For instance, due to the poor living environment, there was outbreak of cholera (hazard) in England, which killed about 54,000 people (disaster) (Ratcliffe, 1982). This underlined the need for an urban planning profession. As Ratcliffe, (1981) puts it, urban planning as a profession, had its roots in the Public Health Act of 1848 and the Housing Act (Shaftesbury) of 1851; (Torrens) of 1868 and (Cross) of 1875 all of which were consolidated into a major Public Health Act of 1875. The Public Health Act of 1875 introduced a set of planning legislations which laid down rules, regulations and procedures including codes or standards in respect of level, width and construction of new streets, standards for roads, the structure of houses, their walls, foundations, roofs, the layout of buildings including the setbacks, external space requirements, sanitary facilities and other infrastructure facilities and services, procedures for development as well as granting powers to demolish dwellings, which were found to be unfit for human habitation. This set of rules, regulations and procedures was imposed to ensure that people would live in a safe environment and thus avoid possible hazards and their impacts.

Basically, planning rules, regulations and procedures are imposed for the purpose of securing amenities, and a convenient, aesthetic and safe living environment. In other words, rules, regulations and procedures related to urban planning are very important to avoid unnecessary disaster risks and to minimize the impacts of hazards. Just to cite some examples, certain standards of roads are recommended in residential settlements to ensure easy accessibility within and outside the neighbourhood/settlement. A settlement with proper road accessibility facilitates easy movement and in the event of a fire outbreak, fire engines can easily be used for rescue purposes. Setbacks and plot coverage are provided to ensure that there is enough air circulation within the settlement, thus limiting the possibility of the spread of air related diseases such as TB and, in the event of a fire stopping its impacts from spreading all over and affecting other housing units.

Equally important, areas for public services are provided within the settlements/ neighbourhoods to enable community members to have access to public services within a reasonable walking distance. For instance, a settlement/neighbourhood with police security services is safer from criminal events and in the case of a 
crime occurrence, the affected can be attended to very quickly unlike what happens where such services are either not available or can be obtained only very far away. It is also worth noting that planning rules and regulations restrict development within high-risk areas such as flood prone areas and areas for quarry mining. In summary, planning rules, regulations and procedures are very essential to avoid/reduce the vulnerability of human settlements to risks, thus ensuring that people live in a safe and healthy environment.

In ensuring that what has been discussed above is achieved, each stakeholder in the urban development process has a role to play. Whereas people have to ensure that they abide by the laid down rules, regulations and procedures when undertaking developmental activities in urban areas, the urban planners and managers have the responsibility for ensuring that the laid down rules, regulations and procedures are properly followed and enforced. The point to emphasize here is that rules, regulations and procedures for urban development are there to ensure that urban areas offer good and safe living environments, thus avoiding/minimizing hazards and their impacts. This can only be achieved where such rules, regulations and procedures are followed properly by those who are responsible. Experience however shows that what has been pointed out above is hardly ever followed. It is on the basis of this general assumption that this study was carried out with the aim of understanding the regulations and procedures of planning in Tanzania; the extent to which they are followed and, where they are not followed, their implications to for disaster and disaster risks; the coping initiatives adopted by local communities to reduce risks and their level of success or failure; and finally deriving lessons and recommendations for disaster risk reduction in urban areas.

The study adopted the case study strategy with the former Kunduchi Quarry Site being the window of investigation. The approach followed included a review of relevant literature, interviews with government officials at municipal and subward (mtaa) ${ }^{\mathrm{ii}}$ levels, interviews at mining companies and small-scale miners and finally interviews with community members at the quarry site and in its vicinity. The discussion and analysis below starts with an account of the procedures, rules and regulations for development in urban areas in Tanzania, after which the Kunduchi Quarry Site case is discussed to see whether it complied with the legislation.

\section{Procedures, rules and regulations for urban development in Tanzania}

This section examines the procedures, legal and institutional framework that governs the development of land in urban areas in Tanzania. It also discusses the 
main actors in the development process, as well as their roles and mandates. It begins by highlighting the procedures that have to be gone through in developing in a new planning area. Because the centre of discussion in this research on disaster risk reduction focused on an area which once used to be a quarry site, emphasis is also placed on the legal framework and procedures that are supposed to be followed in developing such an area.

\section{Sites for residential development}

The legal basis for urban planning in Tanzania when this study was being conducted was the Town and Country Planning Ordinance (Capacity 378) of 1956 as amended in 1961. This ordinance was supported by several legislations and subsidiary legislations such as the Local Government (Urban Authorities) Act No. 8 of 1982, as amended in 2002, and the Land Act No. 4 of 1999, as amended in 2004, the Township (Building Rules) Cap 101, the National Environmental Management Council Act No. 19 of 1983, and the Application of Planning Consent Regulations of 1964.

Sites for residential development in Tanzania are usually designated in Master Plans or Strategic Urban Development Plans (SUDP) for large and medium sized cities and Interim Land Use Plans for small towns. The general planning schemes are made following the declaration by the Minister responsible for town and country planning, for an area to be a planning area. The Minister has to consult the Local Authority within which the area to be declared is situated. The Human Settlements Development Division in the Ministry for Lands and Human Settlements Development prepares the General Planning Schemes. However, the Ministry may delegate power to any organ to prepare General Planning Schemes whenever it is necessary.

\section{Layout/subdivision plans preparation and approval}

The urban councils (Local Authorities) are preparatory authorities responsible for preparing detailed schemes commonly referred to as layout plans, subdivisions plans or Town Planning (TP) Drawings of the area designated in the Master plans, SUDP or interim land use plans. This mandate is given to the Local Authorities under Section 59(e) of the Local Government (Urban Authorities) Act of 1982 and Section 18(c) of Cap 378.

However, following the Ministry's guideline of 1988, the Human Settlements Development Division or the Regional Town Planning Offices are also given the mandate of preparing detailed schemes. The detailed layout plans specify areas for different activities. Usually, the contents of detailed layout plans include resi- 
dential plots, commercial and industrial plots, areas for community facilities like schools, hospitals, dispensaries, clinics, markets, playgrounds and the like. Apart from these, it includes also areas for circulation. Moreover, as plans are made to achieve certain objectives, be they social, economic, political or environmental, detailed schemes are also made for that purpose. The subdivision schemes so prepared have to meet certain standards prescribed by the Government in the Government notices, orders, technical instructions and circulars commonly referred to in pursuance of human settlements development. After preparation, the plans have to go through the approval process including presentation of the plans to the respective council's Urban Planning Committee (UPC) for ratification before the preparatory Authority forwards them to the Director of Human Settlements Development in the Ministry for Lands and Human Settlements Development for approval on behalf of the Minister.

\section{Survey and approval of layout/subdivision plans}

The Land Surveying Section of the Local Authority or a private firm commissioned by the Land Surveying Section of the Local Authority undertakes a survey after the approval of the Town Planning Drawings by the Director of Human Settlements Development. However, before the commencement of surveying works, the Land Surveying Section or a commissioned firm has to seek a surveying permit from the Director for Surveys and Mapping. When a survey permit is granted, survey works commence. All survey works are handed over to the Director of Surveys and Mapping for approval and recording. Copies of the approved survey plans are returned to the Local Authority.

\section{Acquisition of land and compensation}

Before any kind of development is undertaken on the land within the planning area, the Local Authority has to clear the interests of third parties, in other words, those with interests regarding the land. This is done by paying compensation to the affected persons. Before the new Land Act No. 4 of 1999, compensation was limited to unexhausted improvements. The situation at present is that compensation is paid based on the market price of the land as land now is recognized to have value. When the interests of the third parties are cleared, the Local Authority becomes the legal occupier of land.

\section{Land servicing}

Upon clearing up the matter of the interests of third parties and before allocating land to the developers the existing policy and legislative framework provides that the basic infrastructure services and community facilities have to be provided 
(United Republic of Tanzania, 2000: 25). These include a road network and drainage system, water supply, electricity, educational and health facilities to name but a few. Although it is the responsibility of the Local Authority to ensure that the basic services are provided, the current changes in the policy framework advocate that the implementation of this can be done under a partnership arrangement with utility agencies and the private sector. The Local Authority retains the coordinating role and ensures that national standards and laid down legal procedures are adhered to. The provision of the basic services by the Local Authority is very much dependent on the revenue collected by the Local Authority. In addition, Local Authorities also receive a subsidy from the central Government. The costs that are incurred for providing the services are supposed to be recovered from the successful plot applicants. Where the Local Authority ventures, with the utility agencies or the private sector, to provide services, the resources so used are expected to be recovered from the developers who use such services.

\section{Land allocation}

Based on the existing legal and policy framework, applications for land occupation by individual land developers are supposed to be given effect after services have been provided. The procedure is that the would-be land developers fill in the application forms from the Local Authority Land Office. In the forms the applicants are supposed to indicate among other things their names, addresses and nationality, areas they prefer, type of housing density required and types of development they wish to make. Completed application forms are submitted to the Land Office that receives and processes applications made by the developers. Depending on the number of plots available and the ability of the applicants, the Land Office compiles a list of applicants and upon completion submits a list of successful applicants to the urban planning committee for approval. The committee is usually made up of the Director of the respective council, some council members and Local Members of Parliament. It includes also several Functional Officers (Town Planner, Engineer, Land Officer, and Land Surveyor) who are invited members. The Local Authority Land Office writes letters of offer to successful applicants. The letter of offer sets out the duration of tenure (33, 66 or 99 years), rent payable, premium payments and other charges, use and building conditions. If the offer is accepted, successful applicants pay fees to revenue office and service charges to the Ministry. Upon production of receipts for these charges, the Local Authority Land Office verifies such payments. After verification, it drafts the Title and requests the commissioner for Land Development Services to register it. The Commissioner's office crosschecks the validity of the title and, if 
satisfied, issues a Certificate of Occupancy (Title) to the applicant. The applicant also has to satisfy the Commissioner for Land that he/she is the real person referred to in the title. He/She does this by taking an oath in a court of law or by being identified by a known and respected person like the Commissioner of Oaths/Advocate.

\section{Application for a building permit}

Upon receipts of the Title, the owner of the plot prepares architectural designs and working drawings for the building the owner intends to erect. The designs and working drawings have to conform to all building standards and regulations, which pertain to the area and density. The drawings must be submitted to the responsible Town Planning Office within six months from the date of commencement of the offer. The designs and working drawings once submitted to the Local Authority are circulated to various technical sections/departments for endorsement. Once they are endorsed, the drawings are presented to the Urban Planning Committee (UPC) for approval. If approved, the Local Authority engineer issues a building permit to the applicant. This is done in compliance with the Township (Building) Rules (Cap 101) Ordinance.

\section{Actual plot development}

After being issued with a building permit, the owner of the plot mobilizes the resources required for development. Construction must commence within six calendar months of the date when the building permit is issued. Beyond this time limit, the permit expires. The erection of the building must be completed within 36 months (three years) of the effective date of the Certificate of title. Before commencement of the construction works, the plot owner is supposed to submit two days' written notice to the Local Authority stating the date on which the construction work will commence. This is done to enable the Local Authority of the respective area within which development is to take place to exercise its role of controlling and monitoring development. This task is mandated to the Local Authority under section 36 of Cap 378. Erection of buildings has to be done in accordance with the approved architectural drawings and designs.

\section{Housing development in an area formally used for quarry mining}

Experience in Tanzania, especially in large cities like Dar es Salaam, shows that mining areas are among the disaster risk prone areas. Such areas are informally changed into residential housing settlements after the exhaustion of mining activities or even while the mining activities are still being conducted. The major disaster risks associated with such settlements include the following: 
- Air pollution from dust, which may lead to respiratory diseases such as TB, pneumonia and bronchitis. This is due to the fact that residents breathe air which is contaminated by dust.

-Diseases associated with inadequacy of municipal services as these settlements are regarded as illegal settlements and therefore no attention is paid by the government to the provision of services to the people.

- By nature these settlements are full of open pit mines. During heavy downpours, the pits fill with storm water. This makes the settlements unsafe especially for children who may drown in the water. .

-As a result of mining activities, soil remains rough/not so compact. This makes the settlements more vulnerable to landslides, thus creating more risks for residents to lose their lives and properties.

- Explosive materials are used to break down rocks. In most cases rock particles are thrown all over the area thus endangering the lives of the people and their properties.

The Mineral Policy of Tanzania (1997) and the Mining Act (1998) are the policy and legal instruments that regulate mining activities in Tanzania. Human settlements development, as mentioned earlier, was regulated by Cap 378 (1954, as revised in 1961) and supported with several pieces of legislation, subsidiary legislations and policies.

The Mineral Policy of Tanzania (1997: 8) states categorically that one of the challenges of the mining sector in Tanzania is to ensure environmental protection and management. In addressing this challenge the Mineral Policy (1997:9) states clearly that the objective is to minimize or eliminate the adverse social and environmental impacts of mining development. To ensure that environmental protection is attained, the Policy (1997:22) articulates that rules should be established for setting up reclamation funds to reinstate land for alternative uses after mining. This means that upon exhaustion of mining activities in an area, the process of reclamation of that land has to be undertaken before that particular land is converted for other uses including residential development. The mining procedures and regulations clearly state that it is the grantee of the mining licence who is supposed to undertake land reclamation before handing over the land to the Ministry responsible for mining. Because urban land falls under the jurisdiction of the Local Authority, the reclaimed land has to be handed over to the responsible Local Authority so that the piece of land may be re-planned in accordance with the procedures outlined above. 


\section{Urban planning practice and emerging Disasters and Disaster Risks in the former Kunduchi quarry site}

\section{Locational characteristics}

The Kunduchi quarry site is situated in Dar es Salaam city, Kinondoni municipality. The site falls within the Kunduchi Mtongani area, $20 \mathrm{~km}$ away from the city centre. The site lies between Bagamoyo Road, which is on the western side and part of the Kunduchi Mtongani residential area, which is in the eastern part. Tegeta River, which runs from the western part towards the eastern part, forms the northern boundary. It is also worth noting that just beyond Tegeta River there is the Tegeta residential area as well as the Kunduchi military base.

\section{Population and Housing characteristics}

The majority of households within the quarry site, which accounted for about $80 \%$ of the total households, are those which had been undertaking quarrying activities in the area for over 10 years until July 2006 when this study was done. The exercise of counting housing units in the quarry area undertaken by the subward government for two days in mid-March 2005 shows that 262 houses were counted. The total number of houses according to the mtaa Chairman could go up to 300 houses, as a few houses had not yet been counted. The estimated total population staying in the area was about 1,500 people.

\section{Disasters and Disaster Risks in the Kunduchi study area}

The dominant disaster and disaster risks that the former Kunduchi quarry site experienced include exposure of the people to dust pollution which led to respiratory diseases, deaths, injuries and property damage by explosive materials and the outbreak of diseases due to poor access to services. The section below discusses in detail these types of disaster and disaster risks including their sources, extent, vulnerability level and their impacts on the community. It is worth noting that the existence of conflicting land use activities, i.e. residential and mining within the area, is what had given rise to the situation.

\section{Exposure of people to dust pollution}

Sources of dust pollution

Dust pollution was wide spread in the settlement especially during the dry season. Sources of dust included dust emerging from crushing machines. There were twenty- one (21) companies, which were still undertaking quarrying activities in the area. During extraction of rocks the crushing machines produced dust, which spread all over the area. 
Dust was also produced by small-scale miners who crushed gravels and stones by hand. There were two different types of small-scale miners who were observed in the area. The first group constituted those who stayed in the area and the second group was made up of those who stayed outside the area and only entered it for quarrying activities. Some of the miners who constituted the first group undertook their mining activities right from their residential houses. Available statistics at the mtaa government office indicated that there were about 1,500 small-scale miners in the area. On average 200 lorries went in and out of the settlement to load stones, gravels and crush dust for building purposes daily. These moving vehicles produced more dust, which spread all over the settlement.

\section{Extent of the problem and who were vulnerable}

Dust pollution immediately affected the people who stayed in the area. As indicated earlier, a total population of about 1,500 people resided in the area. In a sample of 30 households interviewed, 90\% indicated that they lived and worked within the area and small scale mining activities were their main employment opportunity. This means that this section of the population was being affected by dust pollution day and night, thus putting them at a very high risk of acquiring diseases associated with dust pollution such as TB. Physical observation in the area revealed the accumulation of dust on walls, windows and doors of the houses within the area. It is also worth noting that children were the most vulnerable section of the population, who were being affected most by dust pollution. In every household visited during the interviews, the majority of the children met were coughing and their bodies were covered on dust. The discussion with the physician who ran a private dispensary nearby the area revealed that people who were exposed to dust pollution are likely to acquire respiratory diseases, which include TB, pneumonia and bronchitis as well as skin diseases. Statistics obtained from the dispensary in connection to the impact of quarrying operations in the area are as presented in the bar-graph below. These cases were referred to Mwananyamala municipal hospital for further treatment.

The illustration shows that for the period from 1992 to 2006, which covers fourteen years, there were 23 reported cases of TB, 43 cases of skin diseases and 61 cases of injuries. However, the number of cases could have been more than these because according to officials of the dispensary not all cases were reported and attended to at the dispensary. The message that is drawn from these statistics is that people who stayed within the area were at a risk to their health. The problem of dust pollution and its health impacts seemed however to be viewed differently 
Figure 1: Reported cases of injuries, respiratory and skin diseases for the period 1992-2006

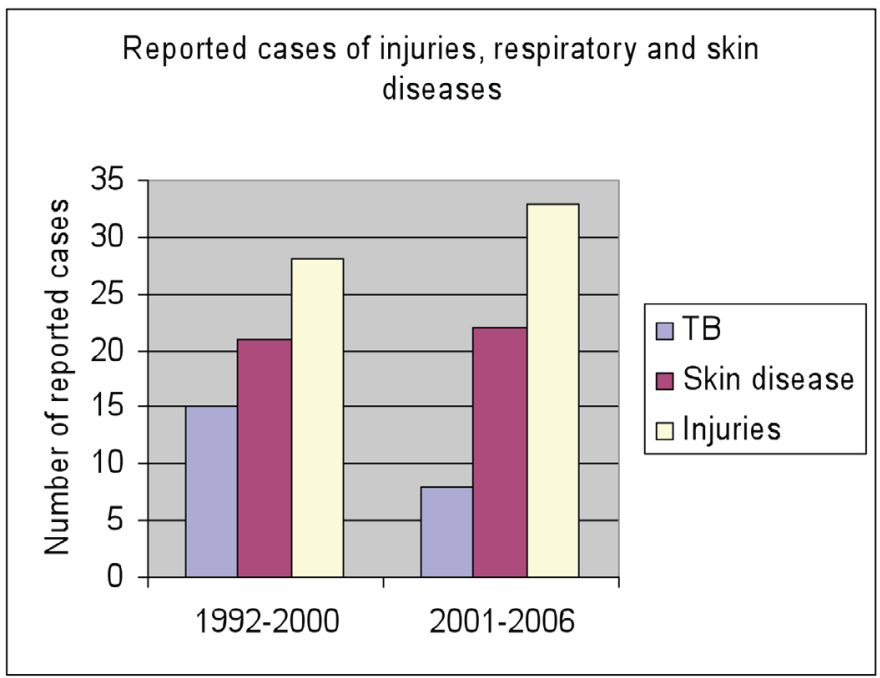

Source: Kunduchi Mtongania Mecco Dispensary records, March 2006

by the people who stayed in the area. There are those who perceived this situation as a normal problem like any other problems. This group indicated that they had been performing quarrying activities in the area with their families for sometime and they did not see any risks in staying in the area. To qualify this one respondent said;

Why do you think (referring to the author) that we are being affected by dusts that come out of the quarrying activities? Even the moving cars along the earth roads produce dust and yet people still board the cars.

The other group of people observed that they were at a high risk by staying in the area as for most of the time they were breathing polluted air. The narration above shows that disasters and disaster risks in the area were viewed relatively especially by those who were affected. A survey in the nearby settlements revealed that the quarrying activities in the area also had an impact on the neighbouring communities as well. People in these settlements, which include Tegeta, Mbezi Salasala and Kunduchi Mtongani, indicated that they were very much affected by dust pollution that was coming out of the quarrying operations. According to them, they had several times submitted to the responsible authorities their requests to have the quarrying activities closed down but without success. 


\section{Deaths, injuries and property damage from explosive materials and land- slides}

In facilitating the extraction of stones, gravel and crush dusts (very fine dusts from gravel) for building and construction purposes, both the mining companies and small scale miners used explosive materials (dynamite). In most cases this practice resulted in property damage and risk to human life. Interviews with the mtaa Chairperson, which was confirmed by the residents, revealed that there had been several reported cases when properties had been damaged and people hit by explosive materials. The Chairperson said that for the past five years from 2005, his office had received about five (5) cases of deaths, which were caused by either being hit by stones resulting from explosions or by landslide. Interviews with the residents revealed different answers. Whereas others indicated three cases, some said that there were more than five cases of deaths. However, the fact is that death had been experienced. With respect to injuries, they said that there were many cases. One respondent said that he had witnessed one person who died after being hit by a stone. More than ten (10) cases of houses being damaged by explosive materials, were reported during the interview. It was also revealed that there were many other cases of houses which had been affected because the effects of the explosions were also affecting as well Tegeta, Mbezi Salasala and Kunduchi Mtongani, which are the surrounding settlements. When expressing his views on this issue, one respondent said:

We are staying in an environment which is full of uncertainties because at any time one can be hit by a stone and die or get a physical disability.

It is worth noting that because the explosions took place in the day time when children were playing within the settlement, this group of people seemed to be more vulnerable and at high risk of being hit by the explosive materials/particles. Another respondent said that there was a time when one mining company was using heavy dynamite. Before an explosion the company had to stop even the moving vehicles to avoid them being damaged and causing injuries to people on board. During an informal talk in a nearby restaurant, one person who works with one academic institution based in Dar es Salaam and who owns a house in Mbezi Salasala, about 500 metres away from the case study area, stated:

The people who stay within this quarry site must be staying in fear. Can you imagine one day I went to see my house only to find that it had a very big hole on the roof? When I asked what transpired, I was told that a big stone resulting from the explosive rocks in the quarry site hit a roof and destructed the iron sheet and ceiling board leaving a hole. 
Another respondent stated that they were very fearful especially of their children losing their lives from landslides as, by nature, children liked playing and they could come across a place where the soil was not properly intact.

\section{Risk of outbreak of diseases because of poor services}

Among the essential services for human beings are the water supply and sanitation. A water supply service was not available in the settlement but instead people obtained it from the nearby settlements. Interviews with the residents revealed that they had taken individual initiatives to supply tap water to their compounds. Some of the house owners interviewed confirmed that they had submitted their applications for home water connection to the Dar es Salaam Water Supply and Sanitation Services Company (DAWASCO), which is the water utility agency for Dar es Salaam city. It was observed that some of the water pipes, which supplied water to the nearby settlements, passed through the area.

The most remarkable service noted in the area, which posed a health risk to the people, was sanitation. The type of sanitation used by the people was pit latrines. However, not all households had this facility. Out of the 30 households interviewed, 54\% were found neither having nor using pit latrines, instead they obtained this service from the small bushes and within the open pits. This situation was much exacerbated by small scale miners who came from outside the settlement as the open pits were their only alternative places for sanitation services. Observations made revealed the presence of human wastes within the open pits and small bushes. It was obvious that whenever it rained these human wastes contaminated the rainy water. Though there was not any reported case of death resulting from poor sanitation, such as cholera, it is worth noting that this unhealthy situation could eventually lead to loss of lives unless mitigation measures are taken. As it is the case with the other risks discussed, children seemed to be more vulnerable to this unhealthy living environment because of their tendency to play in the standing water.

\section{Environmental degradation}

Following the unregulated mining activities in Kunduchi, the area was experiencing a very serious problem of environmental degradation. Observable indicators of this phenomenon included a substantial loss of vegetation cover as almost all vegetation cover had been cleared; and the presence of extensive pit holes ranging from small to huge all over the area as portrayed in the photographic image below which was taken by the Ministry responsible for urban planning in 2000. A fact worth pointing out is that land in the area had lost its quality to attract invest- 
ment. In view of the extent of the degraded environment, it was obvious that restoration of the area to its normal condition would definitely involve a substantial amount of resources.

\section{Contributing factors to this situation}

\section{Kunduchi quarry site in the context of the 1979 Dar es Salaam Master Plan}

The 1979 Dar es Salaam Master Plan was set to develop in three stages. Stage I covered the first five years (1979-1984). It focused on accommodating a city population of 1.3 million people. In this development period, the case study area was earmarked as a quarry site. Being zoned as a quarry site meant that no other uses than quarrying activities were allowed in the area. In other words, development within the area was restricted to only quarrying activities. Residential housing developments were restricted and the nature of the buildings allowed was restricted to those that supported quarrying activities only. Stage II of the Master Plan was the interim plan and it covered the next five years (1985-1989). This stage focused on accommodating the population of 1.6 million people of the entire city of Dar es Salaam. This stage still maintained the case study area as a quarry site. However, the interim land use plan provided that as development of

\section{Photo 1: Kunduchi quarry site and the adjacent settlementsriod 1992-2006}

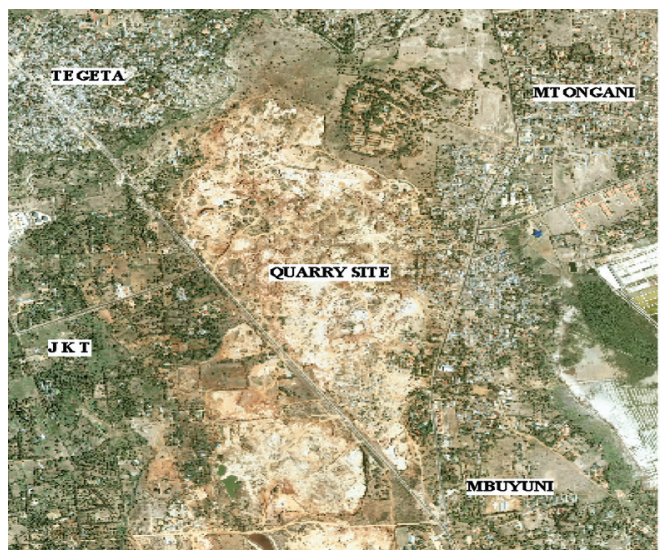

Source: Survey and Mapping Division, Ministry of Lands and Human Settlements Development, 2000.

Mbezi Beach areaiii expanded northwards, the extensive sand and gravel quarries in the Kunduchi area should be closed and the area redeveloped for residential purposes. The map below was obtained from the 1979 Dar es Salaam Master Plan and it shows the case study area (where the arrow points) in respect to the two phases discussed. 
Figure 2: Land use in study area, 1985-1989

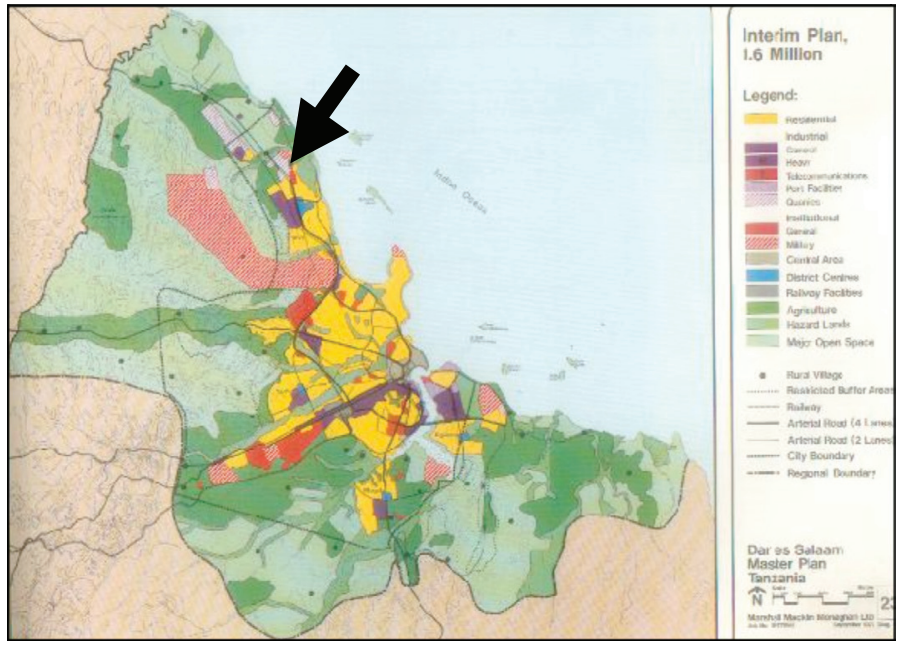

Source: The 1979 Dar es Salaam Master Plan

Stage III of the Master Plan, which covered a period of ten years (1990-1999), was intended to accommodate the total City population of 2.5 million people. Within this planning period, the case study area as shown in the map below (where the arrow points) was zoned as a residential area. Under the development policies, standards and conditions which relate to quarry sites, the Master Plan stipulated that levelling, grading and replacing of top soil for rehabilitation and restoration should be carried out so that the land could be returned to a condition acceptable to the City Council and suitable for other uses such as residential. It is worth pointing out that the Master Plan had a very clear vision of the urban expansion of Dar es Salaam city, which could go beyond the Mbezi planning district as well as the quarry site. This is why the Master Plan categorically recommended the closure of the quarry site and re-planning of the same for residential use. This decision was also aimed at avoiding the conflicting land uses between residential and mining that might arise should the area continue to serve the purpose of quarrying activities. This decision of the Master Plan meant the Ministry responsible for mining could no longer issue mining licences to the mining companies during this period. In the context of Tanzania planning practice, it was the Kinondoni Municipal Council, the Ministry responsible for Urban Planning, the Ministry of Energy and Minerals and the individual quarry operators who were expected to ensure that the recommendations of the Master Plan (a legal document) were implemented. The recommendations of the Master Plan were not adhered to and the Ministry responsible for mining continued to issue mining licences. 
Figure 3: Land use in study area, 1990-1999

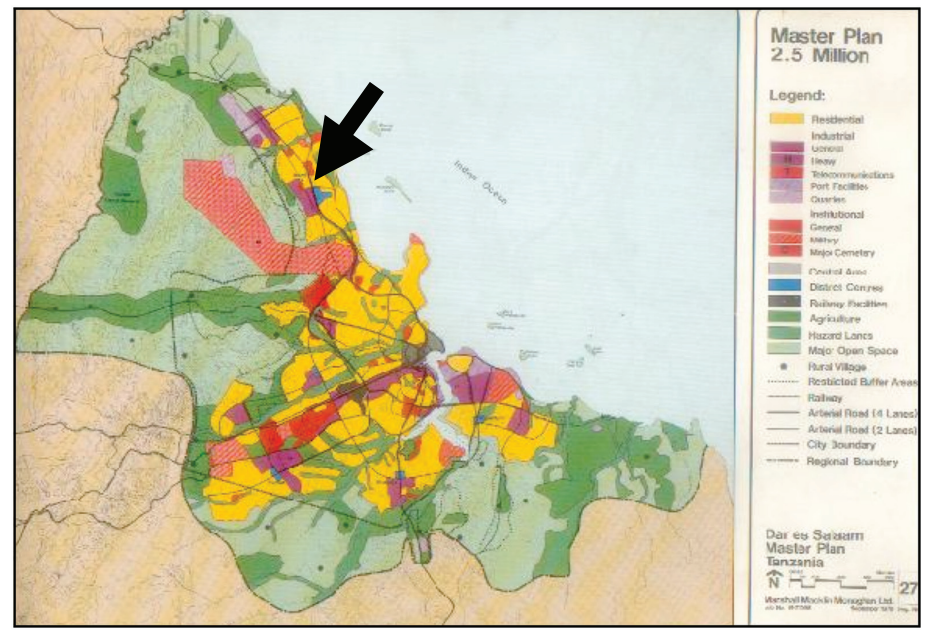

Source: The 1979 Dar es Salaam Master Plan

\section{Residential housing development within the quarry site}

Residential housing development within the quarry site started in 1993. By this year some of the large companies, which possessed mining licences within the area had closed down their activities because of the exhaustion of the stones. It should be noted that these companies did not fulfil the mining regulations that required them to undergo land infill of the areas where they were operating their quarrying activities and hand back the area to the Ministry responsible for mining before the Ministry handed it to the municipal council. There were another twenty-one (21) large companies, which continued with the extraction of stones and gravel. It was during the early 1990s that small-scale miners started also to invade the area for the purpose of exploiting these building and construction materials to sustain their livelihoods. According to the interviews with the residents, and authenticated by the mtaa Chairperson, apart from the extraction of building and construction materials, these small scale miners started as well to undertake land infill for some places within the area for purposes of constructing residential houses which they felt could offer them and their families accommodation. On the other hand, the Kunduchi mtaa government started to subdivide and allocate land to the people who needed it for residential purposes. Some of the house owners in the area are not and they neither used to be small-scale miners. This suggests that the quarry site was invaded and developed into residential housing by different categories of people including the small-scale miners. 
According to the respondents who own houses in the area, the process adopted by the mtaa government to allocate land included the following:

- The land aspirant presented a request letter to the mtaa government from his/her mtaa councillor indicating the desire of the aspirant to be allocated a piece of land.

- The mtaa government had to sit and scrutinise the request.

- If the request was accepted, the aspirant had to pay a fee amounting to Tshs. (5,000/- (five thousand) ;).

- Upon paying the fee, the aspirant was allocated land as well as issued a letter, which authorized him/her to act as a bona fide member of the area. The sizes of the land were determined by pacing.

It is worth noting that the Mwananchi Engineering and Construction Company (MECCO), which was among the companies undertaking quarrying activities in the area, had constructed some temporary structures for its employees to support its mining activities as stipulated in the Mining Act. When the company closed down its activities, its workers who were occupying these temporary structures had to improve them and they started their permanent residence together with their families in the area. Basically, three forms of land acquisition existed, namely through allocation by the mtaa government, improvement and occupation of the former MECCO temporary structures put up by the company to support its mining activities, and through individual encroachment. However, it is worth pointing out that according to the law, these ways used to acquire land were illegal. The Land Act No. 4 of 1999, which applies in the urban areas, Chapter 378, which was the principal legislation for urban planning and the Local Government (Urban Authorities) Act of 1982 recognize the Ministry of Lands and Human Settlements Development and the urban authorities in which the land in question is situated (in this respect, the Kinondoni municipal council) as the legal authorities for land allocation. The process of land allocation by the mtaa government, as it was revealed during the interviews, was done without the knowledge of the Ministry and the council. Another very important observation to note here is that the changing of the area into residential land, contrary to the existing legal procedures, could have been avoided if the municipal council had properly played its role of development control. As residential housing development and occupation continued, quarrying activities by small-scale miners and large companies, which did not cease their activities, continued unchecked. From 1993 when Kunduchi quarry site started being developed into residential housing until March 2006, about 300 houses had already been constructed. 


\section{Government Intervention}

\section{Proposal for sanitary landfill and District Centre}

In 1997, four (4) years after the area had illegally been developed into residential housing, the council prepared a plan for the area (Drawing No. TP/DSM/01/198) as shown in the map below, proposing part of the area to be a sanitary land fill and part as a District Centre. The plan was accepted by the Kinondoni municipal council's Urban Planning Committee (UPC) in the same year (1997) and it was approved by the Ministry responsible for Urban Planning in 1999. Proposing this new land use, meant the uses stipulated in the 1979 Dar es Salaam Master Plan - Stage III of the Development Plan, which is residential, ceased. The duration of the Master Plan was to cease in 1999. However, it should be noted that if the 1979 Master Plan had been properly adhered to, the quarrying activities in Kunduchi area could have come to an end in 1990.

\section{Issuing of demolition order to property owners}

In 1999, two (2) years after the council had produced an approved plan, which proposed the area for sanitary landfill and District Centre; the council issued a demolition notice/order to property owners in the area to demolish their properties. In response property owners filed a case in the Primary Court of Law (Civil Case No. 198/1999). Through their lawyer, they also requested the Court of Law to issue an injunction order to the council not to exercise demolition of their properties until their primary case was heard. The Court granted an "Exparte Temporary Injunction". According to the Kinondoni municipal council, the decision of the Primary Court to impose an injunction order was one sided, as the council had not been consulted on the matter. The council through its lawyer filed an appeal in the High Court seeking the nullification of the decision of the Primary Court. In December 1999, the High Court nullified the temporary injunction order issued by the Primary Court. Until March 2006, when this research was being conducted, the hearing of the main suit was yet to be carried out and the people were still staying in the area.

\section{Closure of the mining activities by order of the Prime Minister}

On 23 March 2006, the Prime Minister visited the Kunduchi quarry area to assess the damage to the environment that had resulted from the mining activities and housing development in the area. At the end of the tour, the Prime Minister ordered the immediate closure of the mining operations in the area as well as the follow-up of a case in which the house owners in the area sued the Kinondoni municipal council to object to the council's decision to evict them. Following the 
order of the Prime Minister the mining activities in the area stopped immediately.

\section{Coping initiatives to minimize disaster risks in Kunduchi study area}

In view of the persistence of these disasters and disaster risks, what were the local people doing to cope with them? It is the intention in this section to discuss the coping initiatives that the people were applying to minimize the risks and the level of success or failure of such strategies. It should however be emphasized here that only coping strategies against exposure to dust pollution and deaths and injuries to people as well as property damage from explosive materials and landslide are discussed because these are the ones that emerged from this study.

\section{Coping initiatives to minimize exposure to dust pollution}

The most remarkable strategy against dust pollution which was observed in the settlement and which the residents pointed out during the interviews is tree planting around the compounds. The importance of trees to act as filters of air seemed to be well understood by some of the residents in the study area. Despite this initiative, the problem of air pollution was still being experienced. Observations made in compounds where trees were planted revealed the accumulation of dust on the walls, windows and doors. Worth noting is that the majority of residents interviewed indicated that planting of trees was not very much of a solution for dust pollution prevention in the area. The planting of trees was covering only part of the section of the community which had been developed for the past five or more years. New sections in the area, which were being developed into residential sites, were bare.

\section{Coping initiatives against deaths, injuries and property damage from explosive materials and landslides}

It was revealed that in avoiding death and injuries to people, whenever the mining companies apply dynamites, they blew a whistle to alert people to take precautionary measures. The small-scale miners shouted loudly to alert the people. However, one respondent had this observation in connection with this strategy;

When they blow a whistle to alert us we move out of our houses and go to a visible place so that whenever a stone comes we can see it and take precautions.

However, this strategy seemed not to help very much as cases of injuries to people and properties were still persisting. There were different opinions as regards the appropriate measures in ensuring safety of the people and their properties. There are those who proposed the closure of the mining activities as the current prac- 
tices of blowing a whistle and shouting did not ensure their safety, especially that of the children. One respondent questioned their practices by saying:

Even if they blow the whistle and shout, can the children be able to take precautionary measures when they are alone?

Others who associate mining activity with their livelihood strategy indicated that closing down the activities would compromise their livelihoods as the majority of them were dependent on this activity to earn their living.

\section{Emerging lessons from this study and recommendations}

In view of the objectives that this study set out to address, the following could be drawn as lessons and recommendations:

Procedures, rules and regulations governing urban planning in Tanzania are in place. They are very clear and if properly enforced and followed they can contribute towards protecting the people, property and environment from disaster and disaster risks. However, as it is evident from the Kunduchi case study area, these are hardly enforced and followed by either the responsible law enforcing institutions or the developers. In other words there is laxity within the institutions entrusted with the responsibilities of enforcing the laid down planning procedures, rules and regulations and as a result people tend to capitalize on these weaknesses to perform activities which are detrimental to their health, properties and the environment. Serious efforts are needed to enforce the laid down rules and regulations and if there are any shortcomings in the laws (which are beyond the understanding of the researcher), necessary measures should be taken to review them with a view to making them enforceable.

Equally important is the existence of poor communication and coordination mechanisms within the government system leading to non-compliance with the provisions of the plans. The municipal authority, the Ministry responsible for urban planning, Ministry responsible for mining activities and the mtaa (subward level) government all had influence in the quarry but they were working independently without communication and coordination. It is recommended that there is a need to look into the system that the government and its development agencies use for communication and coordination of development activities with a view to improving it. The lines of communication, responsibility and accountability among key actors must be well known by every key stakeholder in development and must be respected. 
Local communities have their own ways of coping with the disasters and disaster risks they are exposed to, but some of the 'coping' responses are not lasting solutions to the disaster risks being faced. Sustainable solutions seem to be known by the local community but they are not adopted for fear of compromising or undermining their existing livelihood strategies.

Equally important, we see a strong connection between poverty and disaster and disaster risks. The majority of the affected section of the population in the area is made up of those who are exposed to the risks of disasters by the nature of the livelihood activities they undertake. If healthy urban living environments are to be sustained, local communities must be enabled to find safe and healthy alternative livelihood activities and accommodations.

The concept of Disaster Risk Reduction (DRR) has by far not yet been integrated into planning practice. As emphasized by the Hyogo Framework for Action 2005-2015, there is urgency in inculcating the culture of disaster risk reduction into development policies and planning. As the urban planning profession is conceived to be a tool for DRR this must well be backed up by deeds. The urban planning process which entails plans preparation and approval, actual implementation, follow-up and monitoring must be adhered to in order to ensure risk reduction in urban areas.

\section{References}

AU-NEPAD, AFDB, UN/ISDR. 2004. Guidelines for Mainstreaming Disaster Risk Assessment in Development.

BUll-KAMANGA, L., DIAGNE, K., LAVELL, A., LEON, E., LERISE, F., MACGREGOR, H., MASKREY, A., MESHACK, M., PELLING, M., REID, H., SATTERTHWAITE, D., SONGSORE, J., WESTGATE, K. and YITAMBE, A. 2003. From everyday hazards to disasters: The Accumulation of risks in urban areas. Journal of Environment and Urbanization, 15(1): 193-203. Apr.

ISDR. 2005. Hyogo Framework for Action 2005-2015: Building the Resilience of Nations and Communities to Disaster. Extract from the final report of the World Conference on Disaster Reduction held in Kobe, Hyogo, Japan from 18-22 January 2005.

KWEKA, C. 2001. Institutional Arrangements for Conflict Management in Quarrying Areas: The Case of Kunduchi Quarry. B.Sc. Dissertation. Dar es Salaam.

MALELE, B. 2000. Land Development Process in the Newly Planned Residential Areas in Dar es Salaam City. B.Sc. Dissertation. Dar es Salaam. 
MECCO DISPENSARY. 2006. Records of Reported Cases of Injuries, Respiratory and Skin Diseases for the Period 1992-2006.

MESHACK, M., LERISE, F., KIUNSI, R., LUPALA, J., MALELE, B., MCHOME, E., NAMANGAYA, A. 2006. Community Initiatives in Managing Urbanization and Risk Accumulation Processes: Lessons from Dar Es Salaam, Tanzania. Research Project done under the umbrella of the African Urban Risk Analysis Network (AURAN).

MINISTRY OF LANDS AND HUMAN SETTLEMENTS DEVELOPMENT. Human Settlements Division. 1999. Government notices, orders, technical instructions and circulars commonly referred to in pursuance of human settlements development. Dar es Salaam.

NGWARE, N. 2003. A Crisis of Urban Settlements in Tanzania: Coping Strategies at Msimbazi Valley Dar es Salaam from a Gender Perspective. Dar es Salaam.

RATCLIFFE, J. 1981. An Introduction to Town and Country Planning. Hutchinson. London.

SURVEY AND MAPPING DIVISION. 2000. An Extract of the Quarry site and adjacent settlements. Ministry of Lands and Human Settlements Development.

UNITED REPUBLIC OF TANZANIA. 2000. Human Settlements Development Policy. Ministry of Lands and Human Settlements Development. Government Printers. Dar es Salaam.

UNITED REPUBLIC OF TANZANIA. 1999. Land Act No. 4. Ministry of Lands and Human Settlements Development. Government Printers. Dar es Salaam.

UNITED REPUBLIC OF TANZANIA. 1998. The Mining Act. Ministry of Energy and Minerals. Dar es Salaam.

UNITED REPUBLIC OF TANZANIA. 1997. The Mineral Policy of Tanzania. Ministry of Energy and Minerals. Dar es Salaam University Press. Dar es Salaam.

UNITED REPUBLIC OF TANZANIA. 1997. The National Environmental Policy. Vice President's Office. Dar es Salaam.

UNITED REPUBLIC OF TANZANIA. 1983. National Environmental Management Council Act (No. 19). Government Printers. Dar es Salaam.

UNITED REPUBLIC OF TANZANIA. 1982. The Local Government (Urban Authorities) Act No. 8. Dar es Salaam.

UNITED REPUBLIC OF TANZANIA. 1979. Ministry of Lands, Housing and Urban Development. Dar es Salaam Master Plan. Marshal Macklin Monaghan Ltd. Dar es Salaam.

UNITED REPUBLIC OF TANZANIA. 1956. The Town and Country Planning Ordinance (Chapter 378. Dar es Salaam. 


\section{Endnotes}

I. Adopted from www.proventionconsortium.org

II. The municipal authority is the local government institution at the level of the municipality, while the sub-ward (mtaa) government is the lowest local government institution in the urban setting.

III. A new planning area by then, located immediate south of the quarry site, which was planned to accommodate services up to the level of a district status. 